MACMILLAN

\title{
Updating
}

for

Business

An MSC Open Tech sponsored project

\section{Preparing to Study by Open Learning}

Foundation Element 
ISBN 978-1-349-81104-5 ISBN 978-1-349-81102-1 (eBook)

DOI 10.1007/978-1-349-81102-1

(C) Crown Copyright 1985

This work was produced by the Business and Technician Education Council under an Open Tech contract with the Manpower Services Commission. The views expressed are those of the authors, and do not necessarily reflect those of the MSC, or any other Government Department.

All rights reserved. No reproduction, copy or transmission of this publication may be made without written permission.

No paragraph of this publication may be reproduced, copied or transmitted save with written permission or in accordance with the provisions of the Copyright Act 1956 (as amended).

Any person who does any unauthorised act in relation to this publication may be liable to criminal prosecution and civil claims for damages.

\section{First published 1985}

Reprinted 1985, 1988

Published by

MACMILLAN EDUCATION LTD

Houndmills, Basingstoke, Hampshire RG21 2XS

and London

Companies and representatives

throughout the world

This Foundation Element was written by Derek Ormerod and Maurice Benington. 


\section{Contents}

Introduction: About This Foundation

Element

1 Introducing Open Learning 6

2 About Open BTEC 8

3 Getting Started 10

4 Reading and Concentration 13

5 The Open BTEC Materials 15

Study Guides

Workbooks

Audio-visual materials

6 Dealing with Assignments 18

7 Getting Help and Support 19

8 The Personal Study Plan 20

9 Finding Out More $\quad 29$

$\begin{array}{ll}\text { Answers } & 30\end{array}$ 